\begin{tabular}{|c|c|}
\hline ARTICLE & $\begin{array}{l}\text { DEPRESSION AS A } \\
\text { JOURNALISM SUBJECT: } \\
\text { exploring the Folha Group's files } \\
\text { (1970-2009) }\end{array}$ \\
\hline $\begin{array}{r}\text { Copyright } \odot 2012 \\
\text { SBPjor / Associação } \\
\text { Brasileira de } \\
\text { Pesquisadores em } \\
\text { Jornalismo }\end{array}$ & $\begin{array}{l}\text { ERICSON SAINT CLAIR } \\
\text { Universidade Federal do Rio de Janeiro, Brazil }\end{array}$ \\
\hline
\end{tabular}

\begin{abstract}
We investigate evidence of the cultural construction of depression in Brazilian media. To this end, we have explored its definition as a journalistic subject by examining the corpus of research materials from Folha Group's newspapers, especially Folha de S. Paulo, over the past forty years. Our approach to the news archives has allowed us to outline four main strategic regions of discourse production, revealed and exemplified in the article. Based on these observations, we have advocated a new perspective for the analysis of the press's role in publishing materials for dissemination of scientific research regarding depression. We will interpret its role not simply as the automatic disseminator of scientific truth, but as the explorer of a gray area of the field of opinion, regarded as a representation of the rubble of circulating knowledge, where what is at stake is the production of the current nature itself of the disorder.
\end{abstract}

Keywords: Depression. Speech. Press. Subjectivity.

\title{
A DEPRESSÃO COMO OBJETO JORNALÍSTICO explorando o arquivo do Grupo Folha (1970-2009)
}

RESUMO - Investigamos indícios da construção cultural do distúrbio psíquico da depressão como uma atualidade midiática no Brasil. Para isso, exploramos sua definição como objeto jornalístico a partir do exame do corpus de pesquisa formado por matérias do Grupo Folha, especialmente a Folha de S. Paulo, ao longo dos últimos quarenta anos. Nossa abordagem do arquivo de notícias permite-nos delinear quatro regiões principais de estratégia de produção discursiva, expostas e exemplificadas no artigo. A partir destas observações, pleiteamos então uma nova perspectiva para a análise da função da imprensa na publicação de matérias de divulgação de pesquisas científicas acerca da depressão. Entenderemos seu papel não simplesmente como disseminadora automática de verdades científicas, mas como exploradora de uma zona cinzenta do domínio da opinião, encarada como representação dos destroços do saber circulante, em que está em jogo a produção da própria atualidade do distúrbio. Palavras-chave: Depressão. Discurso. Imprensa. Subjetividade. 


\section{INTRODUCTION AND SOME ASSUMPTIONS}

Dealing with a research subject involving present-day life implies accepting the challenges of an exciting endeavor: how to propose an analysis that presents new opportunities amid the accelerated proliferation of opinions, knowledge and fragments of discourses which eagerly seek to surround this elusive subject that shares with us the uncertainties typical of those who live the contemporary life? The nebulous phenomenon that is called "depression" and, in particular, its media coverage, forms one of those apparently unconceivable subjects in view of the raucous chatter that they cause. In this text, we faced the challenge of proposing a history of the present, on addressing the construction of the feelings of depression in the Brazilian press based on the analysis of the corpus of research material formed by 178 articles published by newspapers of the Folha Group, especially the newspaper Folha de S. Paulo, between 1970 and 2009. Materials were selected to specifically address the topic of depression as a mental disorder that can be treated. Accordingly, other meanings attributed to depression beyond that of a clinical disorder capable of being treated were excluded'. The archeology of Foucault, certainly more ironic than naive in its proposal, whose "simple file descriptions" continue to inspire us today, taught us that "describing the file suffices".

We began with some important assumptions, whose explanation here we consider essential for following the text. The first one relates to how we look at the history of depression in the press (or the history of the media in a broader way ${ }^{2}$ ). This is an inquiry that does not necessarily discern a pattern of evolution in history (as if the history of depression in the media were a neutral description of a progressive succession of scientific research works on the subject, or even a optimistic progression of the means of construction of the journalistic discourse). On the other hand, we do not endorse discourses which view media power only as a manifestation of the economic power of certain groups. While not ignoring this level of power, we see it as a solidification (powerful, but temporary) of a plural game of relationships that go beyond the large press groups. New Foucaultian echoes are heard here: powers are always powers - intentional, but not subjective.

Secondly, more important than saying repeatedly that the media is a level of power, we are interested in bringing to light its strategies, which are not the same in all cases. Neither media advocating a coup, nor neutral media: our approach avoids saying what the media is, believing it to be more productive, based on the exhumation of its files, 
to say what it does, how it does it, with whom it does it. There is here a clear intention to seek discourse units (FOUCAULT, 2005, p. 30) based on the description of discursive events that challenge us, "how a particular statement appeared rather than another in its place?".

Finally, we must clarify that the analysis of a newspaper's files of articles allows us to produce perhaps only a few hypotheses regarding the intended effects with the aid of certain discursive strategies. Thus we will be able to say nothing about its real effects on the audiences. We may suppose, but without the same rigor that we intend to achieve with the dissection of the intended effects, what would be the possible effects of this discursive circulation ${ }^{3}$. We will not be fatalistic, however. It would not be consistent to ratify a theory of pluralistic power if we ignored the inventive power of the subjects in contact with what circulates in the media every day. This does not prevent us, however, from emphasizing the intended effect machinery based on the dive into a newspaper's file.

Poring over a file of forty years has brought us a great variety of hypotheses, which we will restrict in this text to two segments, given the natural limitation of space: the first segment will focus on discursive production strategies in the dissemination of scientific research regarding depression, which we will summarize in four main lines of action, and then we will debate the premise that the press disseminates scientific truths, proposing an alternative perspective, in which we will situate media's role in the proliferation of something other than a fact, in a sort of gray area of opinion, whose primary focus is on the pure production of news, which we understand based on inspiring texts of thinkers as diverse as Niklas Luhmann, Alain Badiou and Gabriel Tarde.

\section{Depression in the Folha Group}

Why specifically investigate depression in the press as a research subject? If the goal were only to map the discursive strategies of the press in disseminating scientific research in general, the other subjects would also be fruitful: heart disease, global warming, obesity etc. Nevertheless, our special interest in depression is warranted for several reasons. The stunning frequency of the dissemination of scientific research on depression in the media provokes in us a genuine curiosity about the phenomenon. In a superficial evaluation, the media's expansion of depression would ratify the impressive number of world health organizations. Worldwide, the World Health Organization (WHO) estimates that 121 million are depressed. In Brazil, they would represent $10 \%$ of the population. According to the Instituto Nacional 
do Seguro Social - INSS (Brazilian National Social Security Institute), cases of disability retirement for depression increased by $16 \%$ between 2007 and 2008. Finally, sales of antidepressants increased 40\% from 2005 to 2009 in the country.

Still, as communicologists, we avoid discussing the increasing number of clinical cases of depression in recent decades. We do not even endorse (or deny) the "reality" of a clinical entity called depression. This is not to say that we disregard factors of "cause" of what is called (properly or not) depression. We only delimit our field of action: not the actual production of depressing elements, but the discursive production of depression as a mental disorder in the press. As media researchers, asserting how far the discursive contamination of depression in the media generates new depressed persons is beyond our means. However, we do not consider "minor" the study of the conditions for social transmission of the "vogue" of depression. In reality, there lies in fact our most sincere concern.

Let us begin, therefore, with the data collected on the expansion of the "vogue" of depression, as shown in Table 1. Of the 178 subjects studied since the 70's, 55\% of them are in the last decade (until 2009).

Table 1: Depression in the Folha Group. Percentage of the total of 178 articles consulted by decade

\begin{tabular}{|c|c|}
\hline Decades & Number of subjects (\% of total) \\
\hline 1970 's & $4 \%$ \\
\hline 1980 's & $10 \%$ \\
\hline 1990 's & $31 \%$ \\
\hline 2000 's & $55 \%$ \\
\hline
\end{tabular}

Source: elaborated by the author

The increase of articles on depression brought with it a plurality of discursive strategies for construction of the disorder as a media subject. There are four main lines of action.

\section{a) Interested selection of specialists consulted}

The articles that reflect scientific themes deepen a common approach in journalism that is the consultation of specialists, individuals whose statements carry with them an authority appropriate to what is investigated by the press professional. Faced with scientific research, we often find specialists' opinion to discuss what has been "discovered". In the specific case of depression, where we have a clear antagonism between biologizing and psychosocial perspectives with regard to understanding 
the disorder, perhaps as important as the scientific research works that are part of the agenda, are the specialists selected to comment on them.

In an article in Folha da Tarde on November 3, 1977 entitled "Depression increases day by day around the world", a psychiatrist is consulted to comment on the expansion of the cases: "The more the population increases, the greater becomes demand of the individual with relation to the environment, forcing him to lead a more active and competitive life, for which he is not prepared. As a result, he becomes the picture of depression." (FOLHA DA TARDE, nov. 3, 1977).

Let us now consider another example, much more recent, in which a neurologist is consulted to comment on the incidence of depression in children and adolescents:

Parent's guilt can also be relieved if the depression is no longer seen as a result of a fault in character or up-bringing. As with any disease, it must be diagnosed and controlled. "It is characterized by the brain's difficulty to use certain substances such as serotonin, dopamine and noradrenalin, to manage information between the neurons", says neurologist John Radvany, from the Albert Einstein Hospital (São Paulo). At stake are genetic predisposition, education and social, environmental and behavioral factors (FOLHA DE S. PAULO, sept. 4, 2003, our italics).

This passage is significant, despite the description of several factors thought to be influential in the development of depression; recurrence to a neurological specialist favors one of these causes, the biological.

The juxtaposition of the foregoing two excerpts from articles, pertaining to dates far apart in time, does not allow us to say, however, that there was an abrupt interruption of the media visibility of psychosocial causes in favor of the disorder's biologization and its attendant indications for treatment, as we can see in Table 2.

Table 2: Treatment of depression in the Folha Group. Percentage of total number of articles consulted by decade

\begin{tabular}{|c|c|c|c|c|c|c|c|}
\hline Decades & \multicolumn{7}{|c|}{ Treatments (\% of total number of articles per decade) } \\
\hline & Drugs & Therapy & $\begin{array}{c}\text { Drugs and } \\
\text { therapy }\end{array}$ & $\begin{array}{c}\text { Natural } \\
\text { Alternatives }\end{array}$ & $\begin{array}{c}\text { Electric shock } \\
\text { or ECT }\end{array}$ & Other & $\begin{array}{c}\text { There } \\
\text { are no } \\
\text { references }\end{array}$ \\
\hline 1970 's & $33 \%$ & - & $17 \%$ & -- & & & $50 \%$ \\
\hline 1980 's & $22 \%$ & $11 \%$ & $22 \%$ & $11 \%$ & $11 \%$ & - & $23 \%$ \\
\hline 1990 's & $33 \%$ & $4 \%$ & $16 \%$ & $5 \%$ & $2 \%$ & - & $40 \%$ \\
\hline 2000 's & $15 \%$ & $5 \%$ & $16 \%$ & $6 \%$ & $2 \%$ & $9 \%$ & $47 \%$ \\
\hline
\end{tabular}

Source: elaborated by the author

Despite the boom in the mentioning of depression treatments by drugs in the 90 s, we would find a reduction of these references in the 
following decade. There is no homogenous growth in the mentioning of depression's biologization at the expense of attention to its psychosocial factors. However, our impression that there probably was an increase in media visibility of the biological causes of depression in recent years could perhaps be justified by the selection of particular specialists who provide the targeting for the published research.

The first strategy can be better understood by comparison with the following.

\section{b) Deficiency in revealing the contradictory aspects of the research work}

We have seen how the selection of certain specialists instead of others implies a specific targeting of the journalistic discourse. In the case of the dissemination of scientific research regarding depression, knowledge of the dispute between a biologizing view and the cultural one does not necessarily generate a debate on the reporting, carried out with the consultation of at least one more specialist for each "trend". Our numbers tell just the opposite, as we see in Table 3. The commonplace principle of journalistic conduct to "hear all sides" certainly idealized (but not for this reason unproductive), is rarely seen in relation to the coverage of depressiono.

Table 3: Second opinion of specialists of articles relating to depression. Percentage of total number of articles consulted by decade

\begin{tabular}{|c|c|}
\hline Decades & Second specialist opinion (\% per decade) \\
\hline 1970 's & - \\
\hline 1980 's & $2 \%$ \\
\hline 1990 's & $9 \%$ \\
\hline 2000's & - \\
\hline
\end{tabular}

Source: elaborated by the author

Publishing a scientific research work and then interviewing a specialist to corroborate it, without seeking to contradict him with the recourse to another specialist of the distinct area, is surreptitiously endorsing uncritically this research work. Nevertheless, this does not authorize us to say that there is a tacit commitment of the press to any specific scientific truth regarding depression (as we maintain in the second part of this article).

Finally, there are other modalities of this deficiency in revealing of contradictory aspects in the discursive construction of 
depression in the press. Many studies are disseminated as "the latest discovery of science", ignoring the historical record of works (and reports) produced on the same topic, often with diverse results. What we notice is that if on one hand, as a diversified group, the materials have no commitment to a specific scientific fact, individually they tend to endorse uncritically the research of the moment as truth. Let us go to Table 4 to explain our perspective. We see how in a large group, there is no strong hegemony of the presence of a specific cause for depression in the articles over the decades.

Table 4: Causes of depression in articles of the Folha Group. Percentage of total number of articles consulted by decade

\begin{tabular}{|c|c|c|c|c|c|c|}
\hline Decades & \multicolumn{5}{|c|}{ Causes (\% of total of articles per decade) } \\
\hline & $\begin{array}{c}\text { Only } \\
\text { Biological }\end{array}$ & $\begin{array}{c}\text { Only } \\
\text { Psychosocial }\end{array}$ & $\begin{array}{c}\text { Biological and } \\
\text { psychosocial }\end{array}$ & Other & $\begin{array}{c}\text { Do not know } \\
\text { for sure }\end{array}$ & $\begin{array}{c}\text { There } \\
\text { are no } \\
\text { references }\end{array}$ \\
\hline 1970 's & $17 \%$ & $33 \%$ & $33 \%$ & - & $17 \%$ & - \\
\hline 1980 's & $44 \%$ & $22 \%$ & $11 \%$ & $6 \%$ & - & $17 \%$ \\
\hline 1990 's & $28 \%$ & $32 \%$ & $9 \%$ & $4 \%$ & - & $27 \%$ \\
\hline 2000 's & $15 \%$ & $27 \%$ & $16 \%$ & $1 \%$ & $2 \%$ & $39 \%$ \\
\hline
\end{tabular}

Source: elaborated by the author

We note that large groups such as "only biological causes" hide articles as disparate as the following: "Depression can be caused by action of a virus" from August 22, 2005 and "Depression can be caused by genetic inheritance of the individual", November 23, 1985. Even within the same group of "biological causes" we find an immense diversity of research works that never interact with each other in the articles. In short, there is a relative balance in the mentioning of the two main explanatory lines for the causes of depression in the articles in general. This balance, nonetheless, is not maintained in individual articles due to the virtual absence of contradictory aspects in the disseminated research works (Table 3), which could be achieved by consulting different specialists, for example.

\section{c) Personal testimonies as ratification of the research}

In the last two decades, there has been a considerable increase in personal testimonies of allegedly depressed persons in articles of the Folha Group (Table 5). More than mere illustration of the research, we maintain that such growth indicates another discursive strategy in the 
production of subject of depression in the media.

Table 5: Personal testimony about depression in articles of the Folha Group. Percentage of total number of articles consulted by decade

\begin{tabular}{|c|c|}
\hline Decades & Personal Testimony (\% per decade) \\
\hline 1970 's & - \\
\hline 1980 's & $6 \%$ \\
\hline 1990 's & $18 \%$ \\
\hline 2000's & $17 \%$ \\
\hline
\end{tabular}

Source: elaborated by the author

The first article of Folha de S. Paulo found that reveals a personal testimony is from June 19, 1989, entitled "Depression: the evil of the world" In it, a man tried to bring his personal coloring to the suffering of the disorder which he underwent:.

In a way, reading, thinking and writing are the only ways I find, at least for now, to deliver me from this huge weight on my heart. I rest awhile, maybe a few months, who knows, and suddenly sink again into that hole. As long as I have the strength, I will write (FOLHA DE S. PAULO, june 19, 1989).

In a first reading, based solely on this example, we could face increased personal testimonies in the articles as a concession of the press to the unique space of subjectivity in that the inventive singularities of the subjects would contrast with the reports dryly prepared by scientific organizations. It happens that most of the testimonies produced, especially in the last two decades, differ a lot from the style adopted by the forerunner quoted above.

In Foucaultian terms, we would find, in these cases, less "aesthetic of the self" than "infamous men" (2009), those individuals whose reality of existence only comes to us because some day they have run up against the railing of power ${ }^{4}$. This is how we noticed a greater homogenization of testimonies found in articles on depression. The "depressed" respondents limit themselves to describing as faithfully as possible their symptoms, which become the main characters in their narratives. This applies to the teenager who sends a letter to the newspaper's specialist seeking to understand what is happening with her and is immediately warned of the possibility of being depressed. We found this example in the article "Depression and anxiety beyond the crisis of adolescence" and reproduce it in two parts, the first being the young girl's letter and the second the opinion of the psychiatrist consulted.

"I'm 18 and I feel strange and sad. My dad picks on me and only 
criticizes what I do. I'm in the year of entrance exams and only study. I've been preoccupied with my thoughts. I feel my body tingle and have shortness of breath. What is happening to me?"

Sadness, strange thoughts, and difficulty in facing life may be signs of depression. The person is unhappy, in low spirits, with no desire to do things. (...) The year of entrance exams is really difficult (...). It is worthwhile to find room in your schedule to seek help from a specialist - a therapist, a psychologist or a psychiatrist who talks to you, checks what is happening, ascertains whether you are really depressed and proposes a treatment. What you cannot do is to keep seeing life with through those dark unfocused lenses (FOLHA DE S. PAULO, sept. 3, 2001).

We could assume that this "pasteurization of the description of oneself' may be linked, especially from the 90 s on, to publication of the fourth edition of the Diagnostic and Statistical Manual of Mental Disorders (DSM), the psychiatrists "bible", which is the basis not only for the creation of diagnoses in doctors' offices but also for the resolutions of governmental investments and regulation of health plans. A symbol of the rise of descriptive psychopathology, which revolutionized the diagnostic methods of mental disorders, the DSM, since its third edition, focuses on the exclusive description of the symptoms of the disorders for the composition of the diagnosis, rather than their more profound contextualization (BEZERRA, 2007). The DSM provides a list of nine symptoms that characterize depression, and the frequency of four or five of them, for at least two weeks would suffice to justify the diagnosis. This descriptive disposition would favor the production of testimony guided by simple descriptions of symptoms. With this, we do not claim that the DSM leads, in a deterministic causal logic, to the production of this pasteurized testimony. In any event, it would not be absurd to think that the increase in the testimony by depressed persons corroborates this trend, also added to the growing revelation of an image of oneself that destroys the bonds of the public and private sectors.

However, going beyond this reading, we would like to take into consideration the role of testimony as a discursive strategy in the articles observed. If it arises in the context of the dissemination of a research work, confirming it, it ends up contributing to the research work's acquisition of concreteness, immediate reality. It is as if we were told that the research is so real that it makes its characters spout out before our eyes.

On 22 November, 2007, for example, the article "Anti-obesity drugs may increase by $40 \%$ the risk of depression" disseminated a Dutch research study on Acomplia, a drug used in treating obesity. The testimony of a woman who was being treated with the drug confirmed what was, 
after all, only one study, subject to discussions and counterchecks:

\begin{abstract}
The teacher Ana Maria Cardoso, 52, is an example. She said she always considered herself a "happy fat" person, but that one month after starting treatment, she began to feel depressed, not wanting to leave home. "I just cried. Suddenly everything became gray", she says. She says it took her at least two weeks to associate the depression with the medication. "So I talked to my doctor, he suspended the medication and, in a few days, I felt like another person" (FOLHA DE S. PAULO, nov. 22, 2007).
\end{abstract}

Gathering the testimony of a housewife on the rising price of rice after the announcement of an increase in inflation is not the same as "illustrating" a story about a research on depression, a subject that can be seen from different perspectives. By making use of this strategy, the article subtly makes the research "more believable".

Let us go on, finally, to the last discursive strategy that we have indicated in our work.

\title{
d) Negligence regarding the research work's preconditions
}

No scientific research work can be separated from its conditions of possibility. We could list a series of them along the lines of Bruno Latour and his indication of different human and non-human actors in a research procedure (2004). However, for what matters to us here, let us confine ourselves to agreeing that a scientific work cannot overlook the historical-social-economic context in which it is produced.

In articles disseminating research on depression, we found a certain neglect of these conditioning factors of the published works. The sponsors of the research works, the political positions of the institutions that produce them and other items are frequently ignored. There are not, however, completely ignored. And it is precisely here that we find in this irregular neglect of the preconditions of the research works published, a new discursive strategy. If they were always ignored, we could say that the preconditions would not be part of the discursive production of the reports studied. This would imply some consequences. This is not the present case, however. Here also, as in the case of the specialists consulted, there is a selection interested in the indication of the production conditions of the research works.

An example will clarify our point. On September 16, 2002, Folha published a little note, "New syndrome identified: a post-vacation depression":

Spanish researchers reported a new syndrome detected in young people, women and children: a post-vacation depression. This is a problem characterized by sleep disturbances, tachycardia, sadness 
and anxiety in people who return to routine activities such as work and study after major breaks (FOLHA DE S. PAULO, sept. 16, 2002, our italics).

Regarding the sources of the above research, the most we know is the nationality of the researchers. Let us not be complacent in attributing such neglect to the fact that the text must conform to the small space devoted to newspaper notes. Another little note, published on June 9, 2003, entitled "Study links sex to depression," is more prudent in the description of the means that enabled the research:

A controversial study, sponsored by the conservative American foundation Heritage, associates sex with depression. According to the research conducted with 2,800 students from age 14 to 17 , approximately $25 \%$ of the girls who are sexually active say they suffer from depression. This percentage is $8 \%$ among those who did not have sex (FOLHA DE S. PAULO, june 9, 2003, our italics).

We not only know the entity that sponsored the research, we are told that it would be "conservative" and that the study would be "controversial". The logic is simple (and simplistic): associating sex with depression is controversial, especially if a conservative organization is financing the study. It is curious that something as astonishing as associating depression with sexual activity, such as the case of "postvacation depression", for example, is not also considered "controversial".

Thus, after the suggestion that the discursive strategies of production of depression as a media subject in articles of the Folha Group follow four main lines of action, let us turn to the second part of the work. Here, we discuss how these strategies would lead to a very distinct role for the press in the dissemination of depression as a clinical entity.

\section{A gray area of opinion}

After analyzing the modus operandi of the four main discursive strategies, asserting simply that the press "disseminates scientific truths" is to ignore its (micro)powers of invention of various meanings for depression. As might be expected, the raw material for such strategies can be found to a large extent in the research works themselves. Nonetheless, this would not allow us to argue that the press only reflects the results disseminated by science, as if there was a secret conspiracy promoted by someone unknown and in unknown terms.

At the same time, contrary to our wagers at the beginning of our doctoral research in 2008, we conclude that the press did not "choose" one side of the dispute concerning the meaning of depression, between socio-cultural and biologizing causes, in favor of the latter. At least in 
Folha Group's newspapers, we found no such hegemonic ratification of the "somatization of subjectivity" (cf. Table 4 above). On the other hand, this surprise coming from the research of Folha Group's did not turn us into Candides. In other words, the fact that the set of articles does not conform to a specific truth advocated by science when it comes to depression does not mean that the press does not corroborate the principle that the favored place for production of truth is, at present, the scientific domain. If, for example, in the same month, the same newspaper publishes two contradictory studies with the appearance of truth (with the aid of discursive strategies such as those mentioned above), we cannot say that this vehicle advocates one particular truth, but we can say that it contributed to making unquestionable the right of science to distinguish between what is true and false.

But if the role of the press is not that of only disseminating a specific scientific fact, neither is it that of the mere propagation of opinion in its most generic sense, since the prestige of the research will automatically provide a place higher than that devoted to an "unscientific" opinion. Neither black nor white, but gray: there is a special region of opinion here that is irreducible both to the truth as well as to a kind of generalized common sense.

The avalanche of research on depression is very likely an indication that the topic is "in vogue" among scientists, but its success in the scientific community does not necessarily justify the social "vogue" of depression that the press helps to disseminate. However, as the main source of opinion (TARDE, 2005; LUHMANN, 1992), the press is itself a potent source of social "vogues". Luhmann inspires us here. From him, we learn that information is all that which is selected according to the criteria of novelty and conflict. The pace of the news is guided by the discontinuity of the day's events. Thus, there is an organized difference between people's lives and the everyday life of the news. This discontinuity creates an impossibility of integrating the two temporalities in play. On the one hand, daily life, in its future, plurality and difference; on the other, the avalanche of statistics, comparative tables and figures poured out daily in the newspapers. Thus, the quantification/accuracy of daily life is rarely "natural". In the case of depression, the proliferation of different studies, with often disparate results, fits in perfectly with this thirst for information (understood as Luhmann suggests) from the press.

We risk saying that the commitment of the press in case of depression is less to scientific truth than to the topic's "current nature" itself. "Current", here, considered not only as that which has just 
happened, but as everything that inspires currently a general interest (TARDE, 2005, p. 8). We could go a little further, perhaps, and say that the commitment of the press with topic of depression (and, possibly, this can be generalized to include other cases) is only to the press itself, to its own operation, with its power to disseminate something that, if it is not true, is also not pure "unfounded" opinion.

This gray area of opinion of ours, in the case of depression, comes very close to the very definition of opinion by philosopher Alain Badiou: opinions are representations without truth, forming the anarchic debris of circulating knowledge. The opinion should not be true or false, therefore: its sole duty is to be communicable, being the food of sociability. Faced with a new truth, opinions change, but without becoming true:

\begin{abstract}
A truth - this is its effect of "return" - transforms the codes of communication, alters the system of opinions. Not that opinions become "true" (or false). They are incapable of this, and, in its eternal multiple-being, a truth remains indifferent to opinions. But they become others. Which means that judgments formerly obvious to opinion are no longer defensible, that they are necessary, that the means of communication change, etc. (BADIOU, 1993, p. 71, our translation).
\end{abstract}

In Badiou, a truth ${ }^{5}$ transforms necessarily the opinion codes. In the case of depression, this transformation is more chaotic, because the researches involving this topic are in constant struggle, in which we find at least two very distinct sides, relatively balanced, although not homogeneous themselves. From this struggle of a thousand soldiers, the press draws its current nature, promoted with its own strategies.

Sociologist Alain Ehrenberg (2008, p. 125) maintains that the communication media contributed to the proliferation of a "grammar of the inner life for the masses" in the case of depression. We can endorse this hypothesis, but only with regard to the effects approved by the publications, without considering the actual use of the subjects based on what comes to them through the media. Moreover, given the plurality of discursive strategies in the formation of the media subject of depression, we do not agree that there is only one grammar of the inner life disseminated. In other scientific areas it is likely that this has occurred with greater fidelity. The vocabulary of the genetic code (in particular after the Genome Project) and language relating to cardiac problems, for example, would produce systems of opinion much more constant and uniform than in the case of depression. Other research works would confirm or refute our wager. About depression, however, much is said, 
but this verbiage is plural, allowing different discourse arrangements.

We maintain that, through very specific and pulverized discursive strategies, the press maintains current the subject of depression, benefiting precisely from the plurality of views that the depressive disorder causes at the very heart of science. It would be, consequently, in this gray zone of opinion that this soft power, producer of scientific current nature, is invented, without being exactly science, without being exactly common sense. In its uncertainties, depression is a favored subject in the production of communicability. Claiming that the press totally corroborates the biologizing view of depression is to ignore its fine discursive strategies. Ironically, when we, researchers, say "Enough of truths" in the wake of our latest philosophical heritage, this gray area of opinion seems to agree with us in a perverse way, which behooves us, therefore, to begin to disentangle.

\section{| NOTES}

1 In our doctoral research, the basis of this article, we propose to be a little more comprehensive: in addition to the file of the Folha Group, we also consulted the file of the magazine Veja, in which we focused on the meanings of the word depression in the past 40 years, going beyond the scientific reports.

2 Cf. Goncalves; Saint-Clair (2008).

3 I am borrowing this nomenclature (intended effects, real effects, possible effects) from Patrick Charaudeau (2010, p 25).

4 Cf. still reading Deleuze about infamy in Foucault, "Foucault conceives an infamy of rarity, that of the insignificant men, obscure and simple, who are only brought to light by complaints, police reports. It is a concept close to Tchekov" (DELEUZE, 2004, p. 102, our translation).

5 "Truth" in Badiou (1993, p. 39) is the real process of fidelity to an event , an immanent break, since there is no "heaven" of truth, based on the conjecture that what makes the process of truth possible - the event - was not among the common uses of a situation. 


\section{REFERENCES}

BADIOU, Alain. Éthique: essai sur la conscience du Mal. Paris: Hatier, 1993.

BEZERRA JR., Benilton. Da contracultura à sociedade neuroquímica: psiquiatria e sociedade na virada do século. In: ALMEIDA, Maria Isabel Mendes de; NEVES, Santuza Combraia (org.). Por que não? Rupturas e continuidades da contracultura. Rio de Janeiro: 7 Letras, 2007.

CHARAUDEAU, Patrick. Discurso das mídias. São Paulo: Editora Contexto, 2010.

DELEUZE, Gilles. Foucault. Paris: Les éditions de Minuit, 2004.

EHRENBERG, Alain. La fatigue d'être soi: Dépression et société. Paris: Odile Jacob, 2008.

FOUCAULT, Michel. A arqueologia do saber. Rio de Janeiro: Forense Universitária, 2005.

A ordem do discurso. São Paulo: Loyola, 1998.

História da sexualidade - A Vontade de Saber. Vol. I. Rio de Janeiro: Graal, 2006.

A vida dos homens infames. In: FOUCAULT, Michel. O que é um autor? Lisbon: Nova Vega, 2009.

GONÇALVES, Márcio; SAINT CLAIR, Ericson. Comunicação e História: perspectivas analíticas..In: HERSCHMANN, Micael; RIBEIRO, Ana Paula Goulart (Org.). Comunicação e História: interfaces e novas abordagens. Rio de Janeiro: Mauad X, Globo Universidade, 2008.

KEHL, Maria Rita. O tempo e o cão: a atualidade das depressões. São Paulo: Boitempo, 2009.

LATOUR, Bruno. "Redes que a razão desconhece: laboratórios, bibliotecas, coleções". In: PARENTE, André (Org.). Tramas da rede. Porto Alegre: Sulina, 2004.

LUHMANN, Niklas. A improbabilidade da Comunicação. Lisbon: Vega, 1992.

MASSARANI, Luisa; MOREIRA, Ildeu de Castro; BRITO, Fátima (Org). Ciência e público: caminhos da divulgação científica no Brasil. Rio de Janeiro: Casa da Ciência/UFRJ, 2002.

TARDE, Gabriel. A opinião e as massas. São Paulo: Martins Fontes, 2005.

\section{Newspaper articles}

"Depressão aumenta dia-a-dia em todo o mundo". Folha de S. Paulo, São Paulo, nov. 3, 1977.

"Depressão pode ter origem em herança genética do indivíduo". Folha de S. Paulo, São Paulo, nov. 23, 1985.

“Depressão: o mal dos séculos”. Folha de S. Paulo, São Paulo, june 19, 1989.

"Depressão e ansiedade vão além da crise da adolescência". Folha de S. 
Paulo, São Paulo, sept. 3, 2001.

"Identificada nova síndrome: a depressão pós-férias". Folha de S. Paulo, São Paulo, sept. 6, 2002.

“Estudo liga sexo à depressão". Folha de S. Paulo, São Paulo, june 9, 2003.

"Depressão em jovem tem feições próprias". Folha de S. Paulo, São Paulo, sept. 4, 2003.

"Depressão pode ser causada por ação de vírus". Folha de S. Paulo, São Paulo, aug. 22, 2005.

Ericson Saint Clair is a doctoral student in Communication and Culture at the Federal University of Rio de Janeiro (UFRJ), Brazil, and Master in Communication. He is the author of "Gabriel Tarde e a Comunicação: por um contágio da diferença" (Gabriel Tarde and Communication: for a contagion of the difference - Editora Multifoco, 2012). His research emphasizes the interfaces between Communication, History and Subjectivity. E-mail: ericsonsaintclair@gmail.com 